\title{
Enhanced Proliferation of Porcine Bone Marrow Mesenchymal Stem Cells Induced by Extracellular Calcium is Associated with the Activation of the Calcium-Sensing Receptor and ERK Signaling Pathway
}

\author{
Jingjing Ye, 1,2 Wei Ai, ${ }^{1,2}$ Fenglin Zhang, 1,2 Xiaotong Zhu, ${ }^{1,2}$ Gang Shu, ${ }^{1,2}$ Lina Wang, \\ Ping Gao, ${ }^{1,2}$ Qianyun Xi, ${ }^{1,2}$ YongLiang Zhang, ${ }^{1,2}$ Qingyan Jiang, ${ }^{1,2}$ and Songbo Wang ${ }^{1,2}$ \\ ${ }^{1}$ College of Animal Science and National Engineering Research Center for Breeding Swine Industry, \\ South China Agricultural University, Guangzhou 510642, China \\ ${ }^{2}$ Guangdong Provincial Key Lab of Agro-Animal Genomics and Molecular Breeding and ALLTECH-SCAU Animal Nutrition \\ Control Research Alliance, South China Agricultural University, Guangzhou 510642, China
}

Correspondence should be addressed to Qingyan Jiang; qyjiang@scau.edu.cn and Songbo Wang; songbowang@gmail.com

Received 2 January 2016; Revised 2 March 2016; Accepted 17 March 2016

Academic Editor: Franca Fagioli

Copyright (C) 2016 Jingjing Ye et al. This is an open access article distributed under the Creative Commons Attribution License, which permits unrestricted use, distribution, and reproduction in any medium, provided the original work is properly cited.

\begin{abstract}
Porcine bone marrow mesenchymal stem cells (pBMSCs) have the potential for application in regenerative medicine. This study aims to investigate the effects of extracellular calcium $\left(\left[\mathrm{Ca}^{2+}\right]_{0}\right)$ on pBMSCs proliferation and to explore the possible underlying mechanisms. The results demonstrated that $4 \mathrm{mM}\left[\mathrm{Ca}^{2+}\right]_{0}$ significantly promoted pBMSCs proliferation by reducing the G0/G1 phase cell percentage and by increasing the $\mathrm{S}$ phase cell proportion and the proliferation index of pBMSCs. Accordingly, $\left[\mathrm{Ca}^{2+}\right]_{\mathrm{o}}$ stimulated the expression levels of proliferative genes such as cyclin A2, cyclin D1/3, cyclin E2, and PCNA and inhibited the expression of p21. In addition, $\left[\mathrm{Ca}^{2+}\right]_{\mathrm{o}}$ resulted in a significant elevation of intracellular calcium and an increased ratio of pERK/ERK. However, inhibition of calcium-sensing receptor (CaSR) by its antagonist NPS2143 abolished the aforementioned effects of $\left[\mathrm{Ca}^{2+}\right]_{0}$. Moreover, $\left[\mathrm{Ca}^{2+}\right]_{0}$-induced promotion of pBMSCs proliferation, the changes of proliferative genes expression levels, and the activation of ERK1/2 signaling pathway were effectively blocked by U0126, a selective ERK kinase inhibitor. In conclusion, our findings provided evidence that the enhanced $\mathrm{pBMSCs}$ proliferation in response to $\left[\mathrm{Ca}^{2+}\right]_{\mathrm{o}}$ was associated with the activation of CaSR and ERK1/2 signaling pathway, which may be useful for the application of pBMSCs in future clinical studies aimed at tissue regeneration and repair.
\end{abstract}

\section{Introduction}

Bone marrow mesenchymal stem cells (BMSCs) not only regulate hematopoietic and other stem cells niches but also have multipotential capacities to differentiate toward osteocyte, chondrocyte, adipocyte, and myocyte [1], performing an important role in regenerative medicine, wound healing, and disease therapy [2]. Pigs exhibit similar structure and function to those of humans and have been widely used as a valuable model in biomedical research such as tissue engineering and cell therapy [3]. In addition to the studies on the isolation and differentiation capacities of porcine BMSCs
(pBMSCs) $[4,5]$, the investigation on $\mathrm{pBMSCs}$ proliferation, which ensures that a large amount of pBMSCs is obtained, is very important. Thus, controlling the proliferation of pBMSCs is an attractive approach to determine the size of the pBMSCs pool and subsequently its possible influence on the maintenance of stem cell niches and multilineage differentiation potential.

Calcium ion, one of the most widely occurring second messengers, is an important cellular signaling component, which has been shown to play a pivotal role in controlling cell proliferation $[6,7]$. Extracellular calcium $\left(\left[\mathrm{Ca}^{2+}\right]_{0}\right) \bmod -$ ulates cell proliferation in various cells, such as myeloma cells 
[8], rat bone marrow-derived progenitor cells [9], osteoblasts [10], preadipocytes [11], and synovium-derived mesenchymal stromal cells $[12]$. $\left[\mathrm{Ca}^{2+}\right]_{0}$ exerts its role in regulating cell proliferation either via calcium influx through calcium channels or by activating the calcium-sensitive receptor (CaSR) [13]. $\mathrm{CaSR}$ is a $\mathrm{G}$ protein-coupled receptor on plasma membrane which senses $\left[\mathrm{Ca}^{2+}\right]_{0}[14]$. Several studies have shown that CaSR is expressed in mesangial cells [15], osteoblasts [10], and preadipocytes [11] and plays a vital role in the regulation of cell proliferation [16].

$\left[\mathrm{Ca}^{2+}\right]_{\mathrm{o}}$ always leads to the increase of intracellular calcium $\left(\left[\mathrm{Ca}^{2+}\right]_{\mathrm{i}}\right)$ and subsequent activation of the intracellular signaling pathway, which regulates cell proliferation. The MAPK signaling pathway, which consists of extracellular signal-regulated kinase 1/2 (ERK1/2), Jun kinase (JNK), and p38 MAPK, plays an important role in controlling cell proliferation in mammalian cells [17]. In particular, ERK1/2 is involved in the proliferation of various cells, such as kidney epithelial cells [18], smooth muscle cell [19], melanoma cell [20], and preadipocytes [11]. ERK elicits its role in cell proliferation possibly through its effect on the cell cycle transition from the G0/G1 phase to the S phase [21] and/or on the expression of cyclin D $[22,23]$.

Although many studies described that $\left[\mathrm{Ca}^{2+}\right]_{0}$ is involved in the regulation of cell proliferation, the role of $\left[\mathrm{Ca}^{2+}\right]_{0}$ in pBMSCs proliferation and the possible mechanisms underlying this process remain unclear. Thus, the present study was designed to investigate the effects of $\left[\mathrm{Ca}^{2+}\right]_{0}$ on pBMSCs proliferation by determining the cell numbers, cell cycle progression, and expression levels of proliferative marker genes. In addition, we sought to explore the underlying mechanisms involved in this process, including the contribution of CaSR and the relevant intracellular signaling pathway. Our results revealed that the enhanced $\mathrm{pBMSC}$ proliferation in response to $\left[\mathrm{Ca}^{2+}\right]_{0}$ was associated with the activation of the CaSR and ERK1/2 signaling pathway.

\section{Materials and Methods}

2.1. Chemicals and Antibodies. Calcium acetate, CaSR antagonist NPS2143, calcium indicator Fluo 3-AM, and ERK kinase inhibitor U0126 were purchased from Sigma-Aldrich. Cell Counting Kit-8 (CCK-8) was purchased from Vazyme Biotech Co., Ltd. (Nanjing, China). DMEM/F12 and fetal bovine serum (FBS) were purchased from Gibco BRL. Polyclonal antibodies against $\beta$-actin, cyclin D1, ERK1/2, phospho-ERK1/2, and p21 were purchased from Cell Signaling Technology Inc. Polyclonal antibodies against CaSR were purchased from Abcam plc.

2.2. Cell Culture and Treatment. pBMSCs were isolated and purified from the bone marrow of postnatal Landrace pigs aged between 5 and 7 days as we previously described [4]. The purified pBMSCs were seeded in a 96-well plate with density of 5000 cells/well and cultured in DMEM/F12 medium (containing $1 \mathrm{mM}$ calcium) supplemented with $10 \%$ FBS, $100 \mathrm{U} / \mathrm{mL}$ of penicillin sodium, and $100 \mu \mathrm{g} / \mathrm{L}$ of streptomycin sulfate in a humidified cell incubator with atmosphere of
$5 \% \mathrm{CO}_{2}$ at $37^{\circ} \mathrm{C}$. The pBMSCs were treated with various concentrations $(1,2,4$, and $6 \mathrm{mM})$ of $\left[\mathrm{Ca}^{2+}\right]_{0}$ for 5 days to investigate the effects of $\left[\mathrm{Ca}^{2+}\right]_{0}$ on $\mathrm{pBMSCs}$ proliferation. In addition, the cells were treated with $4 \mathrm{mM}\left[\mathrm{Ca}^{2+}\right]_{0}$ and/or $0.1 \mu \mathrm{M}$ NPS2143 or $1 \mu \mathrm{M}$ U0126 for 5 days to explore the role of CaSR and ERK in $\left[\mathrm{Ca}^{2+}\right]_{0}$-induced proliferation of pBMSCs, respectively.

2.3. Cell Proliferation Assay. After pBMSCs were cultured with different treatments for 5 days, the cells were then incubated with Cell Counting Kit-8 (CCK-8) reagent $(0.1 \mathrm{mg} /$ well) for $4 \mathrm{~h}$. The number of viable cells was assessed by measuring the absorbance at $450 \mathrm{~nm}$ using a Synergy 2 MultiMode Reader (BioTek, USA).

2.4. Cell Cycle Analysis. pBMSCs were seeded at $1 \times 10^{6}$ cells/per $25 \mathrm{~cm}^{2}$ flask and cultured in presence of $4 \mathrm{mM}$ $\left[\mathrm{Ca}^{2+}\right]_{0}$ and/or CaSR antagonist NPS2143 supplementation for 5 days. Cell cycle status was determined by measuring cellular DNA content following staining with propidium iodide using flow cytometry as previously described [24]. Briefly, the cells were centrifuged and washed twice with ice-cold phosphate-buffered saline (PBS) and then fixed overnight in $70 \%$ ethanol at $4^{\circ} \mathrm{C}$. Fixed cells were centrifuged at $2500 \mathrm{rpm}$ for $5 \mathrm{~min}$ and the supernatant was discarded. Pellets were washed twice and incubated with propidium iodide/RNase Staining Buffer (BD Pharmingen, USA) for $30 \mathrm{~min}$ at room temperature in the dark. DNA content was determined by flow cytometer (Gallios, Beckman Coulter, USA) with excitation at $488 \mathrm{~nm}$ and emission at $630 \mathrm{~nm}$. The data were analyzed using MultiCycle for Windows software. Proliferation index (PI) was calculated according to the following equation: $\mathrm{PI}=(\mathrm{S}+\mathrm{G} 2 / \mathrm{M}) /(\mathrm{G} 0 / \mathrm{G} 1+\mathrm{S}+\mathrm{G} 2 / \mathrm{M}) \times$ $100 \%$ [25].

2.5. Measurements of Intracellular Calcium. The pBMSCs, plated on a 12 -well plate, were cultured with $4 \mathrm{mM}\left[\mathrm{Ca}^{2+}\right]_{0}$ and/or CaSR antagonist NPS2143 for $12 \mathrm{~h}$ and then loaded with Fluo 3-AM $(2 \mu \mathrm{M})$ in the HEPES buffered salt solution (HBSS) ( $\mathrm{NaCl} 137 \mathrm{mM}, \mathrm{KCl} 2.7 \mathrm{mM}, \mathrm{NaH}_{2} \mathrm{PO}_{4} 0.4 \mathrm{mM}$, $\mathrm{CaCl}_{2} 0.9 \mathrm{mM}, 0.5 \mathrm{mM} \mathrm{MgCl}, 10 \mathrm{mM}$ HEPES, and $5.5 \mathrm{mM}$ glucose, $\mathrm{pH} \mathrm{7.4)} \mathrm{for} 30 \mathrm{~min}$ at $37^{\circ} \mathrm{C}$. The loaded cells were rinsed three times with HBSS. Intracellular calcium $\left(\left[\mathrm{Ca}^{2+}\right]_{\mathrm{i}}\right)$ levels were then determined by flow cytometry using a BD FACSAria2 flow cytometer (BD Bioscience, USA) at an excitation wavelength of $488 \mathrm{~nm}$ and an emission wavelength of $525 \mathrm{~nm}$. Data analysis was performed using the FlowJo software.

2.6. Western Blot Analysis. At the end of incubation, the pBMSCs were harvested and washed twice with PBS. Then Western blot was conducted as previously described [26]. Cells were lysed by lysis buffer, and the cell lysates were centrifuged to remove insoluble materials and the protein concentration of each sample was measured. Equal protein amounts of each sample were separated by SDS-PAGE and electroblotted to PVDF membranes (Millipore, Billerica, 
TABLE 1: The primer sequences used for real-time quantitative PCR.

\begin{tabular}{lllc}
\hline Gene & Forward $\left(5^{\prime}-3^{\prime}\right)$ & Reverse $\left(5^{\prime}-3^{\prime}\right)$ & Amplification length $(\mathrm{bp})$ \\
\hline$\beta$-actin & TGTCATGGACTCTGGGGATG & GTGGTGGTGAAGCTGTAGCC & 156 \\
CaSR & GTGCCATAGAGGAAATAAACAG & CCACGGCGATGGTAGAG & 198 \\
Cyclin A2 & CCTTGGAAAGCAAACAGTAAAC & TTGGTCCAGGTAAAGTAACAGC & 148 \\
Cyclin D3 & GGTCCTGGGGAAGCTCAAGT & CATGGCAAAGGTGTAATCTGTA & 163 \\
Cyclin E2 & AAACACCCCACAAAGAAATAGG & CCCAGCTTAAATCAGGCAAA & 105 \\
PNCA & GATGCTGTTGTAATTTCCTGTG & CTCTATGGTAACTGCTTCCTCC & 129 \\
p21 & AGGACCATGTGGACCTGTTG & TTAGGGCTTCCTCTTGGAGA & 173 \\
\hline
\end{tabular}

MA, USA). The membranes were blocked with $5 \%$ nonfat milk in TBST for $2 \mathrm{~h}$ at room temperature and then incubated with different primary antibodies, including anti-CaSR (1:500), anti-cyclin D1 $(1: 2000)$, anti-p21 $(1: 2000)$, antiERK1/2 (1:2000), and anti-phospho-ERK1/2 (1:2000), at $4^{\circ} \mathrm{C}$ overnight. Then the membranes were washed and incubated with different HRP-labeled secondary antibodies at room temperature for $1 \mathrm{~h}$. Finally, the proteins were detected using the enhanced chemiluminescence detection reagents (Beyotime Institute of Biotechnology, Jiangsu, China) with a FluorChem M Fluorescent Imaging System (ProteinSimple, Santa Clara, CA, USA). Protein expressions were analyzed using ImageJ software.

2.7. Real-Time Quantitative PCR. The expressions of proliferative marker genes and CaSR were examined by real-time quantitative PCR as we previously described [27]. Briefly, total RNA was extracted from pBMSCs by using TRIzol reagent (Invitrogen, Carlsbad, CA, USA) according to the manufacturer's protocol and cDNA was synthesized from $1 \mu \mathrm{g}$ of total RNA by the M-MLV Reverse Transcriptase (Promega, Madison, WI, USA) and random primers oligo(dT)18 according to the manufacturer's instructions. $\beta$-actin was used as a candidate housekeeping gene. Real-time quantitative PCR was carried out in Mx3005p instrument (Stratagene, La Jolla, CA, USA) by using SYBR Green Real-Time PCR Master Mix reagents (Toyobo Co., Ltd., Osaka, Japan) and both sense and antisense primers ( $200 \mathrm{nM}$ for each gene). Relative gene expression of each gene between experimental groups was analyzed using the $2^{-\Delta \Delta c t}$ method. Primer sequences (with their respective PCR fragment lengths) were shown in Table 1.

2.8. Statistical Analysis. All data are presented as means \pm standard error of the mean (SEM). Statistical analysis was performed using SigmaPlot 12.5 (Systat Software, Inc., San Jose, CA). Differences between means were determined using Student's $t$-test and a confidence level of $P<0.05$ was considered to be statistically significant.

\section{Results}

3.1. $\left[\mathrm{Ca}^{2+}\right]_{0}$ Promoted the Proliferation of pBMSCs and the Expression of CaSR. To assess the effect of $\left[\mathrm{Ca}^{2+}\right]_{\mathrm{o}}$ on pBMSCs proliferation, the cells were incubated in DMEM/F12 supplemented with various concentrations $(0,1,3$, and $5 \mathrm{mM})$ of calcium acetate for 5 days, with the final concentrations of $\left[\mathrm{Ca}^{2+}\right]_{\mathrm{o}}$ in the medium up to 1 (control), 2, 4, and $6 \mathrm{mM}$. The results of CCK- 8 assay showed that $\left[\mathrm{Ca}^{2+}\right]_{0}$ significantly stimulated pBMSCs proliferation in a dose-dependent manner, with similar promotive effects observed at 4 and $6 \mathrm{mM}\left[\mathrm{Ca}^{2+}\right]_{0}$ (Figure $1(\mathrm{a})$ ). Thus, $4 \mathrm{mM}\left[\mathrm{Ca}^{2+}\right]_{0}$ was selected and used in our subsequent studies. To determine whether CaSR was involved in $\left[\mathrm{Ca}^{2+}\right]_{0}$-induced pBMSCs proliferation, we examined the effects of $\left[\mathrm{Ca}^{2+}\right]_{0}$ on the expression of CaSR. The result of real-time quantitative PCR indicated that the mRNA expression of CaSR was significantly $(P<$ 0.05 ) enhanced by $4 \mathrm{mM}\left[\mathrm{Ca}^{2+}\right]_{\mathrm{o}}$ (Figure 1(b)). Consistently, Western blot results revealed that $4 \mathrm{mM}\left[\mathrm{Ca}^{2+}\right]_{0}$ markedly $(P<0.05)$ increased the protein expression of CaSR (Figures 1(c) and 1(d)). The similar pattern of enhancement of pBMSCs proliferation and CaSR expression implied the possible involvement of CaSR in $\left[\mathrm{Ca}^{2+}\right]_{0}$-induced pBMSCs proliferation.

3.2. Inhibition of CaSR Reversed the Promotive Effects of $\left[\mathrm{Ca}^{2+}\right]_{o}$ on pBMSCs Proliferation. To further elucidate the role of CaSR in $\left[\mathrm{Ca}^{2+}\right]_{0}$-stimulated pBMSCs proliferation, NPS2143, a CaSR antagonist, was used to inhibit CaSR in the present study. As shown in Figure 2(a), NPS2143 $(0.1 \mu \mathrm{M})$ alone had no effect on pBMSCs proliferation. However, NPS2143 significantly $(P<0.001)$ abolished the promotion of pBMSCs proliferation induced by $4 \mathrm{mM}\left[\mathrm{Ca}^{2+}\right]_{0}$. In addition, the results of cell cycle progression analysis via flow cytometry revealed that $4 \mathrm{mM}\left[\mathrm{Ca}^{2+}\right]_{0}$ markedly $(P<$ $0.05)$ increased the proportion of pBMSCs in the $S$ phase and the proliferation index (PI) of pBMSCs and decreased the proportion of pBMSCs in the G0/G1 phase. However, NPS2143 eliminated the effects of $\left[\mathrm{Ca}^{2+}\right]_{0}$ on cell cycle distribution and PI (Figures 2(b) and 2(c)). Furthermore, $4 \mathrm{mM}\left[\mathrm{Ca}^{2+}\right]_{\mathrm{o}}$ significantly increased the mRNA expression levels of cyclins (cyclin A2, cyclin D3, and cyclin E2) and PCNA but decreased the mRNA expression of p21, the inhibitor of cyclin-dependent kinase (Figure 2(d)). Moreover, the elevated mRNA expression levels of cyclins and PCNA and the decreased mRNA levels of p21 induced by $4 \mathrm{mM}$ $\left[\mathrm{Ca}^{2+}\right]_{\mathrm{o}}$ were reversed by NPS2143. Similarly, the increased protein expression of cyclin D1 and the decreased protein level of p21 induced by $4 \mathrm{mM}\left[\mathrm{Ca}^{2+}\right]_{\mathrm{o}}$ were also abolished by NPS2143 (Figures 2(e) and 2(f)). These results showed that the inhibition of CaSR reversed the promotive effects of $\left[\mathrm{Ca}^{2+}\right]_{\mathrm{o}}$ on $\mathrm{pBMSC}$ proliferation, thereby indicating the essential role of CaSR in this process. 


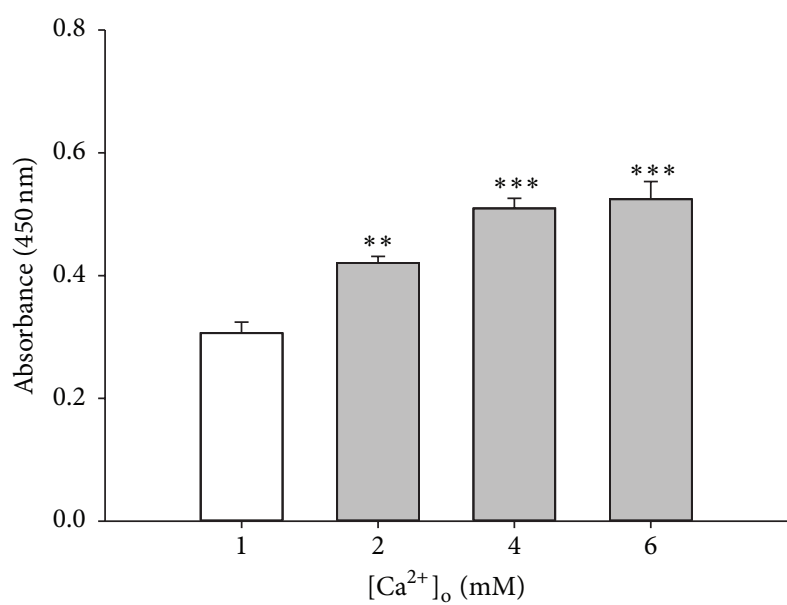

(a)

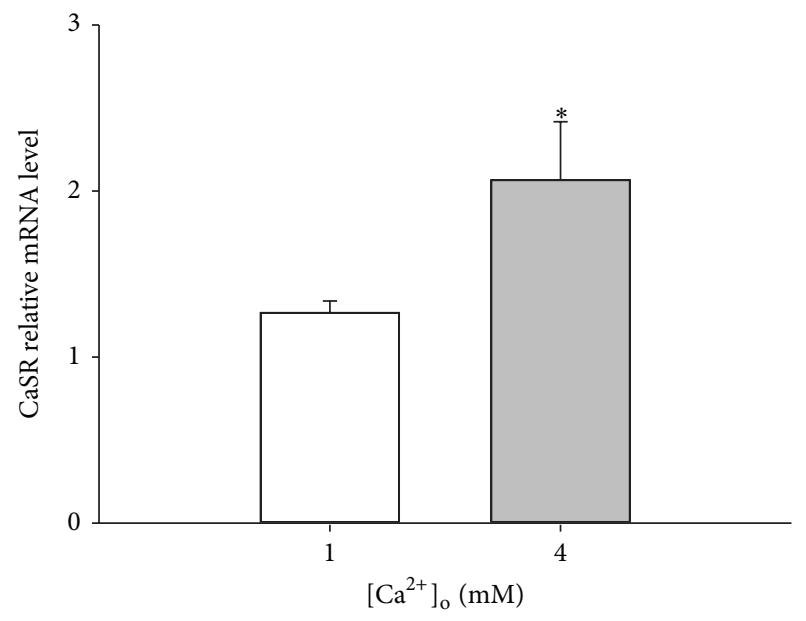

(b)

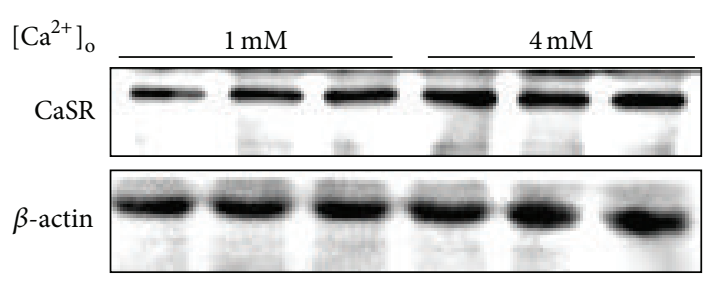

(c)

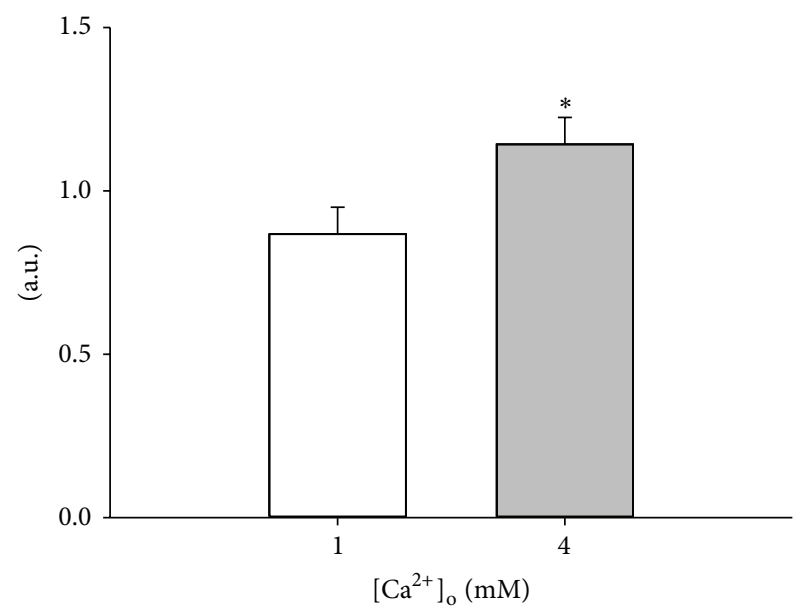

(d)

FIGURE 1: Extracellular calcium $\left(\left[\mathrm{Ca}^{2+}\right]_{0}\right)$ promoted pBMSCs proliferation and CaSR expression. (a) Effect of various $\left[\mathrm{Ca}^{2+}\right]_{\mathrm{o}}(1,2,4$, and $6 \mathrm{mM})$ on the proliferation of pBMSCs $(n=8)$. (b) Effect of $4 \mathrm{mM}\left[\mathrm{Ca}^{2+}\right]_{0}$ on the mRNA expression of CaSR in pBMSCs after 5-day culture. (c) Western blot analysis of CaSR in pBMSCs after 5-day culture. $\beta$-actin was used as loading control. (d) Mean \pm SEM of immunoblotting bands of CaSR; the intensities of the bands were expressed as the arbitrary units $(n=3) .{ }^{*} P<0.05,{ }^{* *} P<0.01$, and ${ }^{* * *} P<0.001$ versus $1 \mathrm{mM}\left[\mathrm{Ca}^{2+}\right]_{\mathrm{o}}$ group (control).

3.3. Elevation of $\left[\mathrm{Ca}^{2+}\right]_{i}$ Level in Response to $\left[\mathrm{Ca}^{2+}\right]_{o}$ Was Blocked by CaSR Inhibition during pBMSCs Proliferation. The high level of $\left[\mathrm{Ca}^{2+}\right]_{0}$ always resulted in the increase of $\left[\mathrm{Ca}^{2+}\right]_{i}$ levels. In order to confirm the occurrence of this phenomenon and to explore the role of CaSR in this process, we examined $\left[\mathrm{Ca}^{2+}\right]_{\mathrm{i}}$ in pBMSCs in the presence of $4 \mathrm{mM}\left[\mathrm{Ca}^{2+}\right]_{\mathrm{o}}$ and/or NPS2143 $(0.1 \mu \mathrm{M})$. As expected, $\left[\mathrm{Ca}^{2+}\right]_{\mathrm{i}}$, which was indicated as the percentage of gated cells (Figure 3(a)) or relative fluorescence (Figure 3(b)), was significantly $(P<0.001)$ increased in response to $4 \mathrm{mM}$ $\left[\mathrm{Ca}^{2+}\right]_{0}$, with an increase pattern similar to that of CaSR protein expression induced by $4 \mathrm{mM}\left[\mathrm{Ca}^{2+}\right]_{\mathrm{o}}$ (Figures 3(c) and 3(d)). However, as shown in Figures 3(a) and 3(b), the significant elevation of $\left[\mathrm{Ca}^{2+}\right]_{\mathrm{i}}$ in response to $4 \mathrm{mM}$ $\left[\mathrm{Ca}^{2+}\right]_{\mathrm{o}}$ was blocked by CaSR inhibition with NPS2143, which also abolished the promotive effect of $4 \mathrm{mM}\left[\mathrm{Ca}^{2+}\right]_{0}$ on CaSR protein expression (Figures 3(c) and 3(d)). These data demonstrated that CaSR inhibition blocked the elevation of $\left[\mathrm{Ca}^{2+}\right]_{\mathrm{i}}$ induced by $4 \mathrm{mM}\left[\mathrm{Ca}^{2+}\right]_{\mathrm{o}}$ in pBMSCs, thereby suggesting that the CaSR-mediated increase in $\left[\mathrm{Ca}^{2+}\right]_{\mathrm{i}}$ in response to $\left[\mathrm{Ca}^{2+}\right]_{0}$ might be involved in the $\left[\mathrm{Ca}^{2+}\right]_{0}-$ promoted $\mathrm{pBMSCs}$ proliferation.

3.4. $\left[\mathrm{Ca}^{2+}\right]_{o}$ Activated ERK1/2 Signaling Pathway during the Proliferation of $p B M S C s$. Increased $\left[\mathrm{Ca}^{2+}\right]_{\mathrm{i}}$ triggered by the high level of $\left[\mathrm{Ca}^{2+}\right]_{0}$ would subsequently activate the downstream intracellular signaling pathway. To explore whether there was a link between CaSR signaling activation and intracellular ERK1/2 signaling pathway, the phosphorylation of ERK1/2 in response to $4 \mathrm{mM}\left[\mathrm{Ca}^{2+}\right]_{0}$ and/or CaSR antagonist NPS2143 were assessed by Western blotting. The results revealed that $4 \mathrm{mM}\left[\mathrm{Ca}^{2+}\right]_{\mathrm{o}}$ led to a significant $(P<0.01)$ increase of the $\mathrm{p}$-ERK/ERK ratio, indicating the activation of the ERK1/2 signaling pathway (Figure 4). Meanwhile, the activation of the ERK1/2 signaling pathway induced by $\left[\mathrm{Ca}^{2+}\right]_{0}$ was reversed by NPS2143 (Figure 4). These results 


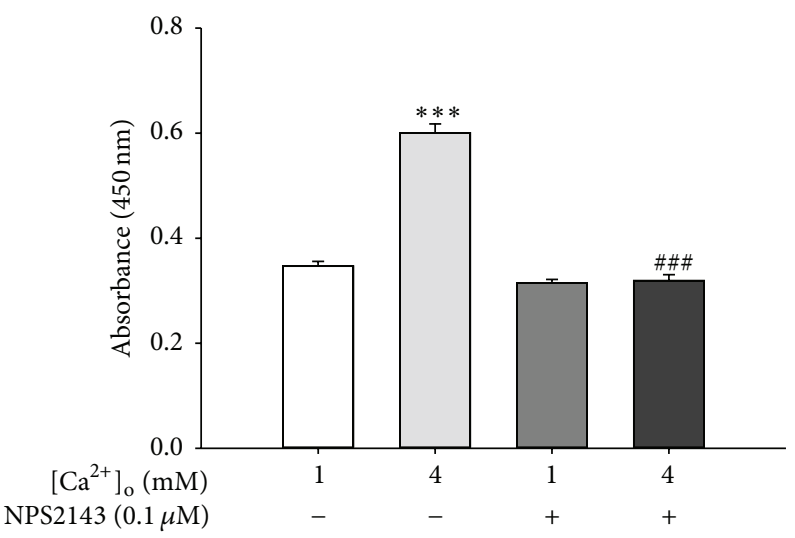

(a)
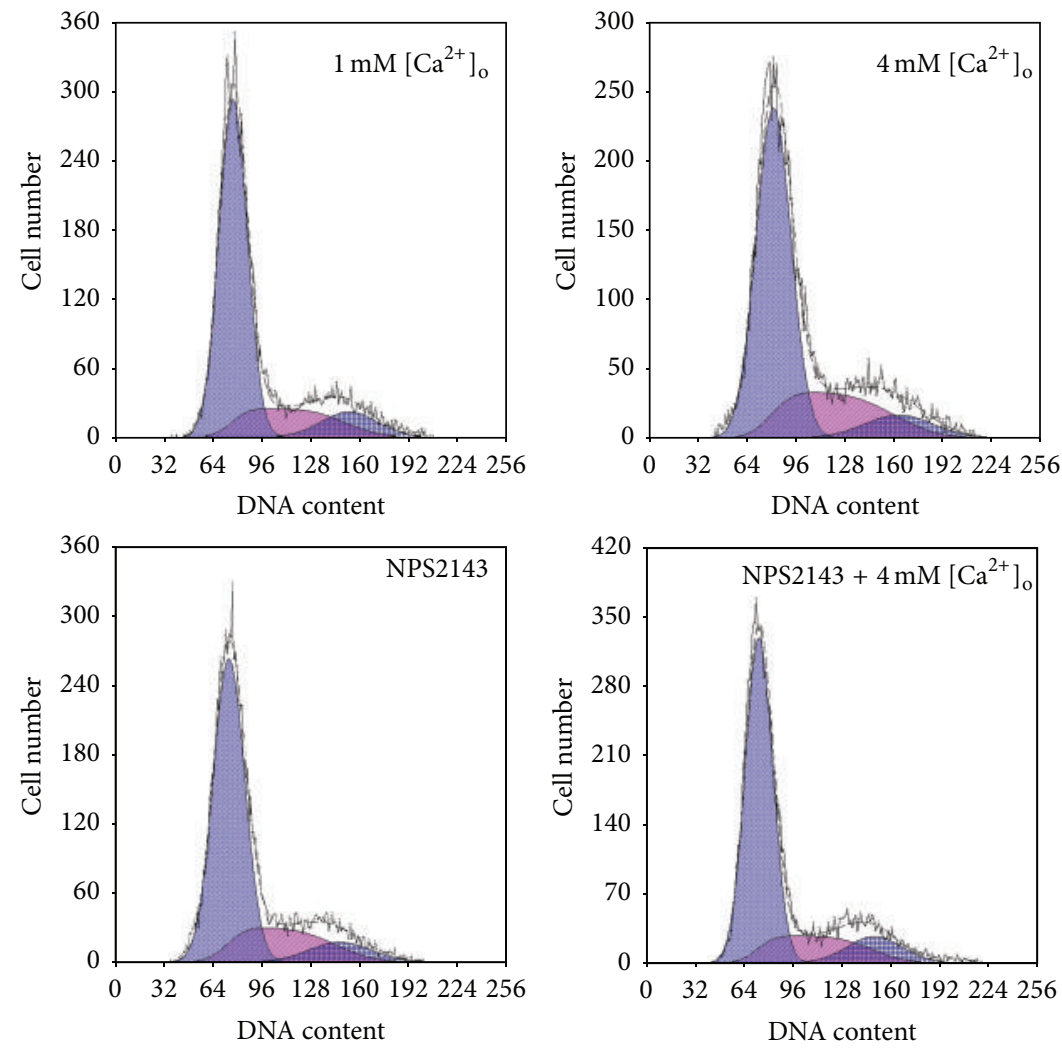

(b)
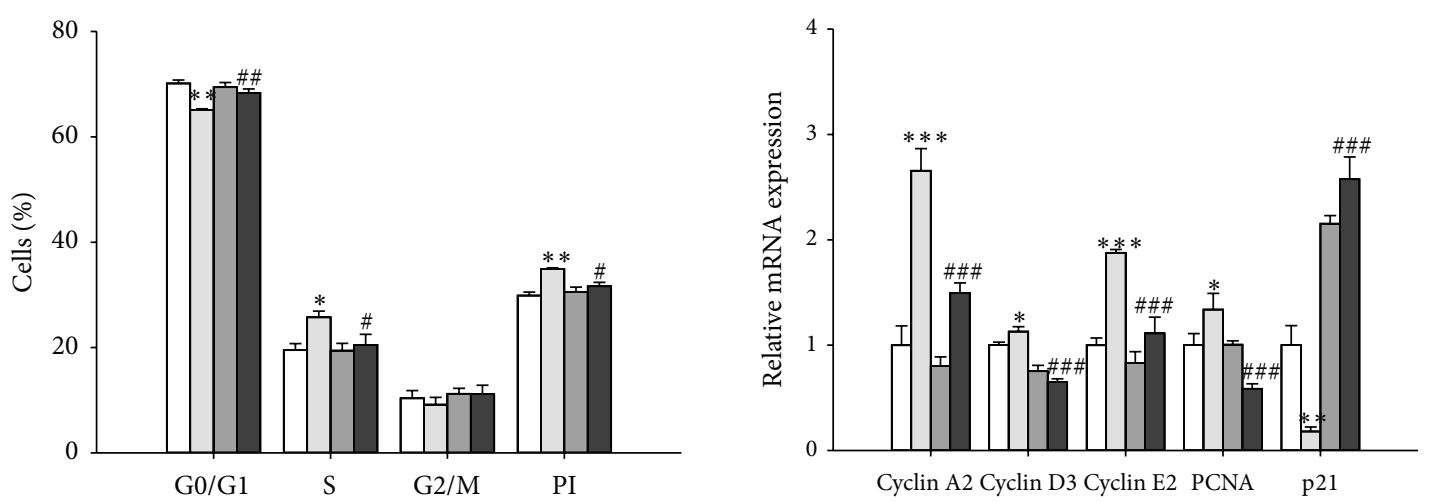

$\sqsubset 1 \mathrm{mM}\left[\mathrm{Ca}^{2+}\right]_{0} \sqsubset 0.1 \mu \mathrm{M} N P S 2143+1 \mathrm{mM}\left[\mathrm{Ca}^{2+}\right]_{0} \rightleftharpoons 1 \mathrm{mM}\left[\mathrm{Ca}^{2+}\right]_{0} \rightleftharpoons 0.1 \mu \mathrm{M} \mathrm{NPS} 2143+1 \mathrm{mM}\left[\mathrm{Ca}^{2+}\right]_{\mathrm{o}}$ $\square 4 \mathrm{mM}\left[\mathrm{Ca}^{2+}\right]_{\mathrm{o}} \quad 0.1 \mu \mathrm{M}$ NPS $2143+4 \mathrm{mM}\left[\mathrm{Ca}^{2+}\right]_{\mathrm{o}}$

(c)

(d)

Figure 2: Continued. 


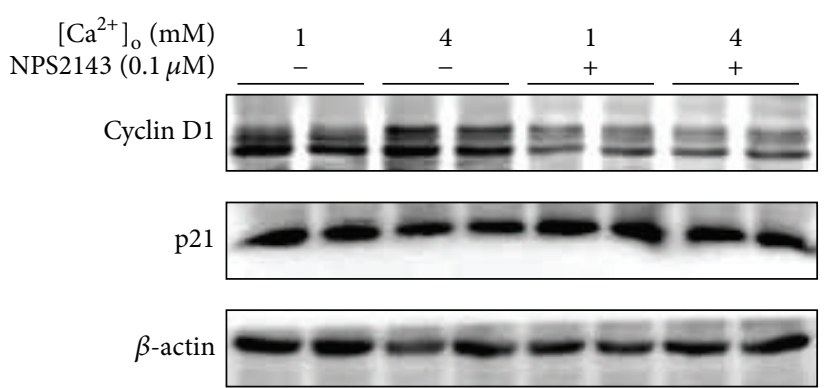

(e)

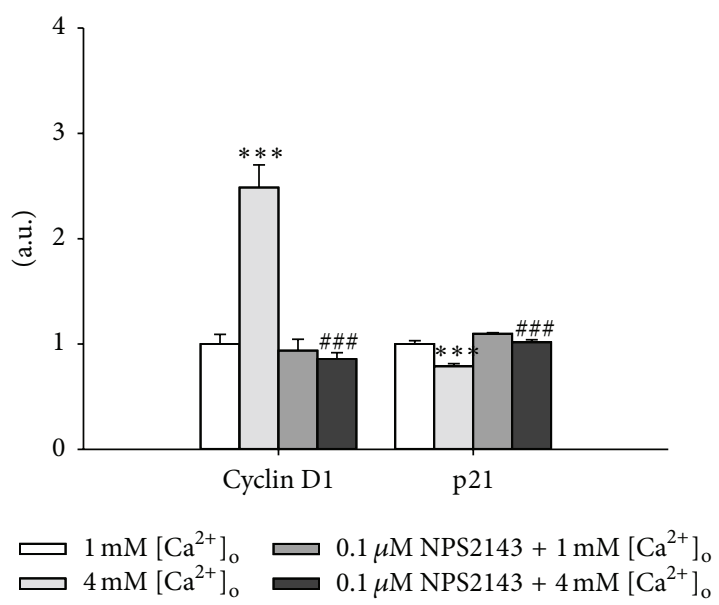

(f)

FIGURE 2: Inhibition of CaSR reversed the promotive effects of $\left[\mathrm{Ca}^{2+}\right]_{0}$ on the proliferation of pBMSCs. (a) Effects of NPS2143 (0.1 $\mu$ M), an antagonist of CaSR, on the proliferation of pBMSCs after 5-day incubation $(n=8)$. (b) Effects of $4 \mathrm{mM}\left[\mathrm{Ca}^{2+}\right]_{\mathrm{o}}$ and/or $0.1 \mu \mathrm{M}$ NPS2143 on the cell cycle progression of pBMSCs. After pBMSCs were exposed to $4 \mathrm{mM}\left[\mathrm{Ca}^{2+}\right]_{\mathrm{o}}$ with or without NPS2143 $(0.1 \mu \mathrm{M})$ for 5 days, the cells were collected and treated according to the protocol in Materials and Methods. The DNA contents were measured with FACScan flow cytometry. (c) Analysis of proliferation index (PI) and the percentage of cells in G0/G1, S, and G2/M phases. (d) The mRNA expression levels of cyclins (cyclin A2, cyclin D3, and cyclin E2), PCNA, and p21 in response to $4 \mathrm{mM}\left[\mathrm{Ca}^{2+}\right]_{0}$ and/or $0.1 \mu \mathrm{M} \mathrm{NPS} 2143$. (e) Western blot analysis of cyclin D1 and p21 in pBMSCs after 5-day culture. $\beta$-actin was used as loading control. (f) Mean \pm SEM of immunoblotting bands of cyclin D1 and p21; the intensities of the bands were expressed as the arbitrary units $(n=4) .{ }^{*} P<0.05,{ }^{* *} P<0.01$, and ${ }^{* * *} P<0.001$ versus $1 \mathrm{mM}\left[\mathrm{Ca}^{2+}\right]_{\mathrm{o}}$ group (control); ${ }^{\#} P<0.05,{ }^{\# \#} P<0.01$, and ${ }^{\# \#} P<0.001$ versus $4 \mathrm{mM}\left[\mathrm{Ca}^{2+}\right]_{\text {o }}$ group.

indicated that the activation of CaSR signaling and the linked intracellular ERK1/2 signaling pathway might be involved in $\left[\mathrm{Ca}^{2+}\right]_{0}$-stimulated pBMSCs proliferation.

3.5. Inhibition of the ERK1/2 Signaling Pathway Abolished $\left[\mathrm{Ca}^{2+}\right]_{0}$-Stimulated $p B M S C$ S Proliferation. To further verify the role of ERK1/2 signaling pathway in $\left[\mathrm{Ca}^{2+}\right]_{0}$-induced cell proliferation of pBMSCs, U0126, a selective inhibitor of ERK kinase (MEK1/2), was applied to inhibit the kinase activity of MEK $1 / 2$ and thus to prevent the activation of ERK1/2 in our study. We determined that the significant increase of p-ERK/ERK ratio in response to $4 \mathrm{mM}\left[\mathrm{Ca}^{2+}\right]_{\mathrm{o}}$ was reversed by U0126 (Figures 5(c) and 5(d)). The findings of CCK-8 assay showed that U0126 $(1 \mu \mathrm{M})$ alone had no effect on the proliferation of pBMSCs. However, U0126 could eliminate the promotion of pBMSCs proliferation induced by $4 \mathrm{mM}\left[\mathrm{Ca}^{2+}\right]_{\mathrm{o}}$ (Figure 5(a)). In agreement, the significant increase in the mRNA levels of cyclin A2, cyclin D3, cyclin $\mathrm{E} 2$, and PNCA and the significant decrease of p21 mRNA levels induced by $4 \mathrm{mM}\left[\mathrm{Ca}^{2+}\right]_{0}$ were also abolished by U0126 (Figure 5(b)). In addition, U0126 reversed the effects of $\left[\mathrm{Ca}^{2+}\right]_{o}$ on the protein expression of cyclin D1 and p21 (Figures 5(c) and 5(d)). These results strongly suggested that $\left[\mathrm{Ca}^{2+}\right]_{\mathrm{o}}$ promoted $\mathrm{pBMSC}$ proliferation through the activation of the ERK1/2 signaling pathway.

\section{Discussion}

In the present study, we determined that $\left[\mathrm{Ca}^{2+}\right]_{0}$ promoted pBMSCs proliferation by regulating cell cycle progression and the expression levels of proliferative marker genes through the activation of plasma membrane receptor CaSR and intracellular ERK1/2 signaling pathway. The proproliferation effects of $\left[\mathrm{Ca}^{2+}\right]_{0}$ have been reported in various cells such as rat bone marrow-derived progenitor cells [9], osteoblasts [10], preadipocytes [11], and porcine synoviumderived mesenchymal stromal cells [12]. In line with these results, we found that $\left[\mathrm{Ca}^{2+}\right]_{\mathrm{o}}$ promoted pBMSCs proliferation in a dose-dependent manner, with the similar promotive effects observed when $\left[\mathrm{Ca}^{2+}\right]_{\mathrm{o}}$ was greater than or equal to $4 \mathrm{mM}$. However, Liu et al. reported that the optimal $\left[\mathrm{Ca}^{2+}\right]_{\mathrm{o}}$ needed for rabbit BMSCs to proliferate was $1.8 \mathrm{mM}$ and the higher level of $\left[\mathrm{Ca}^{2+}\right]_{0}$ did not change cell proliferation [28]. In addition, it was demonstrated that the high level of $\left[\mathrm{Ca}^{2+}\right]_{\mathrm{o}}(7$ or $10 \mathrm{mM})$ slowed the rate of porcine osteoblasts proliferation [29]. Furthermore, Lin et al. found that low calcium $(0.09 \mathrm{mM})$ greatly enhanced the growth rate and extended the lifespan of human adipose-derived MSCs [30]. These discrepant effects of $\left[\mathrm{Ca}^{2+}\right]_{0}$ on BMSCs proliferation might be attributed to the various species and/or culture conditions. In addition, the heterogeneous characteristic of BMSCs should also be considered for the different effects of $\left[\mathrm{Ca}^{2+}\right]_{0}$ on BMSCs proliferation. The pBMSCs used in our study were positive for mesenchymal surface markers CD29 and CD44 and negative for hematopoietic marker CD45 and for the adhesion molecule CD31 and were able to differentiate into adipocytes and myocytes [4], which represented only a subpopulation of MSCs in porcine bone marrow. It should be noted that this study was performed in $20 \%$ oxygen tensions, which are generally used in standard culture. It has been reported that, in the presence of high oxygen tension $\left(20 \%\right.$ to $\left.21 \% \mathrm{O}_{2}\right)$ culture conditions, MSCs derived from human [31], mouse [32], and rat [33] 


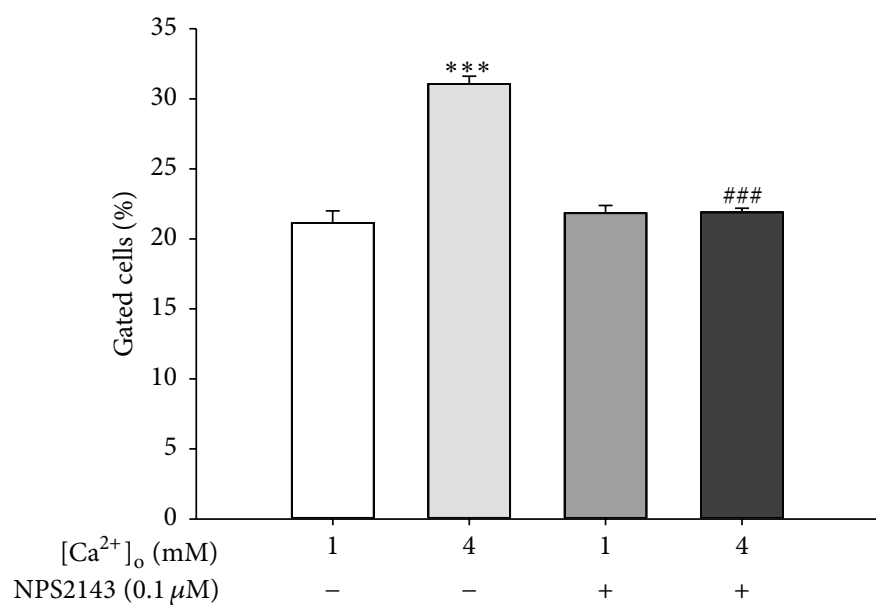

(a)

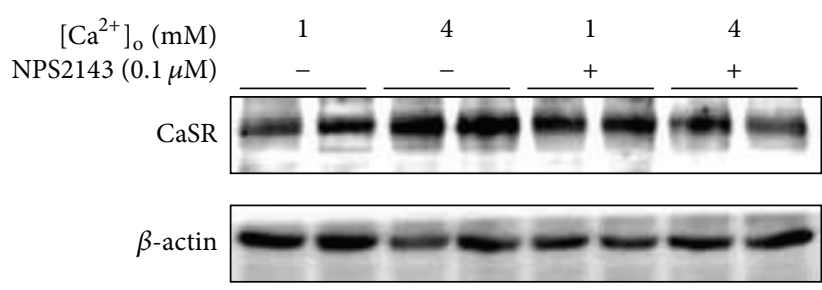

(c)

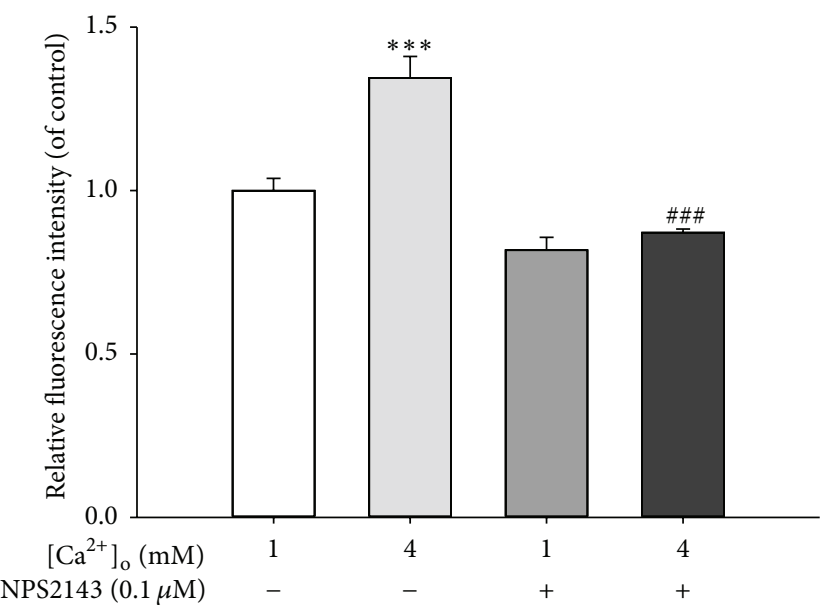

(b)

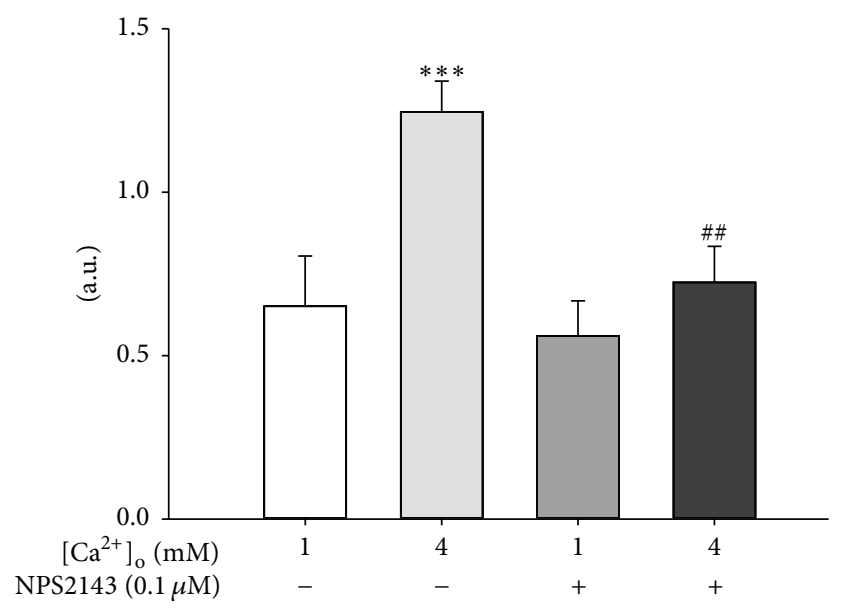

(d)

FIGURE 3: CaSR inhibition blocked the increase of $\left[\mathrm{Ca}^{2+}\right]_{\mathrm{i}}$ in response to $\left[\mathrm{Ca}^{2+}\right]_{\mathrm{o}}$ during the proliferation of pBMSCs. (a) $\left[\mathrm{Ca}{ }^{2+}\right]_{\mathrm{i}}$ of live cells were analyzed by flow cytometry. The percentage of gated positive cells represented the cells stained with Fluo 3-AM. Representation of three independent experiments with similar results. (b) The relative FITC fluorescence intensity of gated positive cells. (c) Western blot analysis of CaSR in pBMSCs after 5-day culture in the presence of $4 \mathrm{mM}\left[\mathrm{Ca}^{2+}\right]_{\mathrm{o}}$ and/or $0.1 \mu \mathrm{M} \mathrm{NPS} 2143$. $\beta$-actin was used as loading control. (d) Mean \pm SEM of immunoblotting bands of CaSR; the intensities of the bands were expressed as the arbitrary units $(n=4)$. ${ }^{* * *} P<0.001$ versus $1 \mathrm{mM}$ $\left[\mathrm{Ca}^{2+}\right]_{\mathrm{o}}$ group (control); ${ }^{\#} P<0.01$ and ${ }^{\# \#} P<0.001$ versus $4 \mathrm{mM}\left[\mathrm{Ca}^{2+}\right]_{\mathrm{o}}$ group.

show lower proliferative activity than that in the presence of low oxygen tension $\left(2 \%\right.$ to $\left.5 \% \mathrm{O}_{2}\right)$ culture conditions. Thus, the effects of $\left[\mathrm{Ca}^{2+}\right]_{0}$ on pBMSCs proliferation in low oxygen tension should be further investigated in future study.

The cell cycle progression and the expression levels of proliferative marker genes (cyclins, PCNA, and p21) were detected to elucidate the stimulatory effects of $\left[\mathrm{Ca}^{2+}\right]_{0}$ on pBMSCs proliferation. In our study, we determined that $\left[\mathrm{Ca}^{2+}\right]_{0}$ significantly decreased the ratio of G0/G1 phase and increased the percentage of the $S$ phase and the PI in pBMSCs, compared with those of control group. These data indicated that $\left[\mathrm{Ca}^{2+}\right]_{0}$ accelerated cell cycle progression from the G0/G1 phase to the $S$ phase and promoted pBMSCs proliferation. It has been implicated that cyclin $\mathrm{D}$ and cyclin $\mathrm{E}$ are required for the transition from G1 to $\mathrm{S}$ phase of the cell cycle, whereas cyclin $\mathrm{A}$ is involved in the initiation and completion of DNA replication during the $S$ phase $[34,35]$. In accord, we detected the elevated expressions of cyclin A2, cyclin D1/3, and cyclin E2 induced by $\left[\mathrm{Ca}^{2+}\right]_{0}$. In addition, the level of PCNA, an essential component for DNA replication machinery [36], was also improved by $\left[\mathrm{Ca}^{2+}\right]_{0}$. By contrast, p21, the inhibitor of cyclin-dependent kinase, was inhibited in the presence of $\left[\mathrm{Ca}^{2+}\right]_{0}$. Thus, these findings indicated that $\left[\mathrm{Ca}^{2+}\right]_{0}$ stimulated pBMSCs proliferation by influencing the cell cycle progression and the expression levels of proliferative marker genes.

$\left[\mathrm{Ca}^{2+}\right]_{0}$ elicits its effects on the regulation of cell proliferation either via calcium influx through calcium channels or by activating CaSR-mediated signaling pathway [13]. Although it has been reported that the voltage-gated calcium channels (VGCCs) antagonist nifedipine exerts antiproliferative effects on rats BMSCs [37], our result 


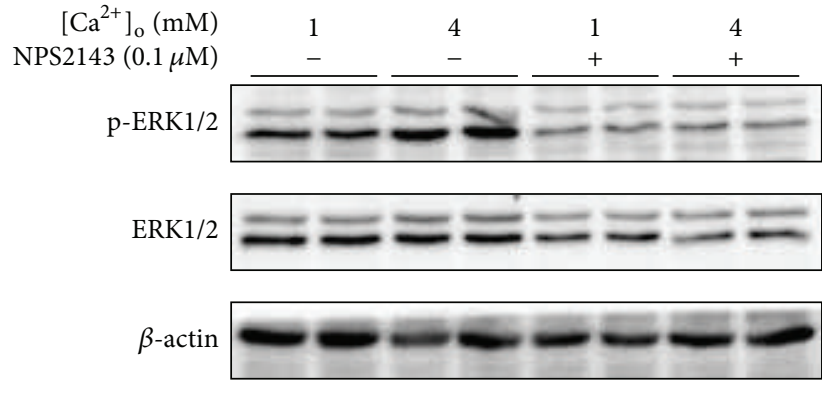

(a)

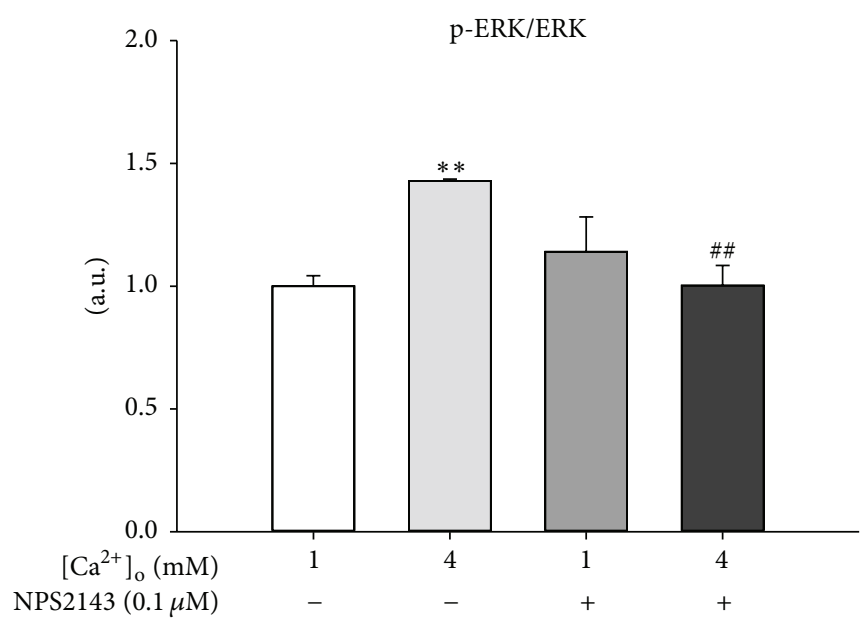

(b)

FIGURE 4: $\left[\mathrm{Ca}^{2+}\right]_{\mathrm{o}}$ activated ERK1/2 during the proliferation of pBMSCs. (a) Western blot analysis of phosphor-ERK (p-ERK) and ERK in pBMSCs after 5-day culture. $\beta$-actin was used as loading control. (b) Mean \pm SEM of immunoblotting bands of p-ERK/ERK; the intensities of the bands were expressed as the arbitrary units $(n=4) .{ }^{* *} P<0.01$ versus $1 \mathrm{mM}\left[\mathrm{Ca}^{2+}\right]_{\mathrm{o}}$ group (control); ${ }^{\# \#} P<0.01$ versus $4 \mathrm{mM}\left[\mathrm{Ca}{ }^{2+}\right]_{\mathrm{o}}$ group.

revealed that nifedipine had no effect on $\left[\mathrm{Ca}^{2+}\right]_{0}$-stimulated pBMSCs proliferation (see the Supplementary Material available online at http://dx.doi.org/10.1155/2016/6570671). In contrast, we found the expression of CaSR in pBMSCs, which was also expressed in mesangial cells [15], osteoblasts [10], preadipocytes [11], and rat BMSCs [38] and played a vital role in the regulation of cell proliferation. In addition, the inhibition of CaSR by NPS2143 reversed the promotive effects of $\left[\mathrm{Ca}^{2+}\right]_{0}$ on pBMSCs proliferation, suggesting the involvement of CaSR in $\left[\mathrm{Ca}^{2+}\right]_{0}$-promoted pBMSCs proliferation. In agreement, it has been demonstrated that activation of CaSR by $\left[\mathrm{Ca}^{2+}\right]_{0}$ contributes to the cell proliferation of human mesangial cells [15] and osteoblasts [10]. In addition, CaSR activation with its agonist increased the cell proliferation of human aortic smooth muscle cells, while CaSR knockdown reduced the cell proliferation [39]. However, Rey et al. described that $\left[\mathrm{Ca}^{2+}\right]_{\mathrm{O}^{-}}$ induced stimulation of CaSR inhibited the cell proliferation of human colon epithelial cells [40]. The opposite effects of CaSR activation on cell proliferation might be caused by the distinguished cell types and varied physiological environment.

A large body of evidence has determined that $\left[\mathrm{Ca}^{2+}\right]_{0}$ can induce $\left[\mathrm{Ca}^{2+}\right]_{\mathrm{i}}$ increment $[10,15,41]$. Consistently, our results showed a significant elevation of $\left[\mathrm{Ca}^{2+}\right]_{i}$ in response to $\left[\mathrm{Ca}^{2+}\right]_{0}$, which was reversed by CaSR inhibition with NPS2143. These finding indicated the involvement of CaSR in the $\left[\mathrm{Ca}^{2+}\right]_{\mathrm{o}}$-induced increase in $\left[\mathrm{Ca}^{2+}\right]_{\mathrm{i}}$ during $\mathrm{pBMSC}$ proliferation. Notably, it was reported that $\left[\mathrm{Ca}^{2+}\right]_{\mathrm{i}}$ can promote cyclin E expression and the initiation of DNA synthesis at G1/S transition, thereby contributing to the completion of the cell cycle [42]. Our results also showed that CaSR inhibition by NPS2143 reversed the promotion of PBMSCs proliferation, the change of cell cycle distribution, and the expression levels of proliferative marker genes (cyclins, PCNA, and p21), which were induced by the high level of $\left[\mathrm{Ca}^{2+}\right]_{0}$. Together, these observations give rise to the idea that the $\left[\mathrm{Ca}^{2+}\right]_{\mathrm{o}}$-induced elevation of $\left[\mathrm{Ca}^{2+}\right]_{\mathrm{i}}$ and the enhancement of pBMSCs proliferation were mediated, at least in part, by activation of CaSR.

Numerous studies have shown that the activation of the ERK1/2 signaling pathway is involved in regulating the proliferation of various cells, including kidney epithelial cells [18], smooth muscle cell [19], melanoma cell [20], and preadipocytes [11]. Accordingly, in the present study, the ERK1/2 signaling pathway was activated by $\left[\mathrm{Ca}^{2+}\right]_{\mathrm{o}}$ and the activation of ERK1/2 was abolished by NPS2143. In addition, the inhibition of ERK1/2 signaling pathway with U0126 reversed the stimulation of pBMSCs proliferation, the alteration of cell cycle distributions, and the expression levels of cell cycle marker genes, which were induced by $\left[\mathrm{Ca}^{2+}\right]_{0}$. These results provided the evidence that $\left[\mathrm{Ca}^{2+}\right]_{0}$ stimulated pBMSCs proliferation, at least in part, via activation of CaSR and the linked intracellular ERK1/2 signaling pathway. However, Tfelt-Hansen et al. found that the activation of p38 MAPK and PI3K but not that of ERK1/2 by CaSR promoted the cell proliferation of rat Leydig cancer cells [43]. The reason for the discrepancy between the study of Tfelt-Hansen et al. and our study might be the different cell types.

In conclusion, our findings demonstrated that CaSR was expressed in pBMSCs and that the enhanced proliferation of pBMSCs in response to $\left[\mathrm{Ca}^{2+}\right]_{0}$ was associated with activation of plasma membrane receptor CaSR, elevation of $\left[\mathrm{Ca}^{2+}\right]_{i}$, and the enhancement of the intracellular ERK1/2 signaling pathway. These data may be useful for the application of pBMSCs in future clinical studies aimed at tissue regeneration and repair. 


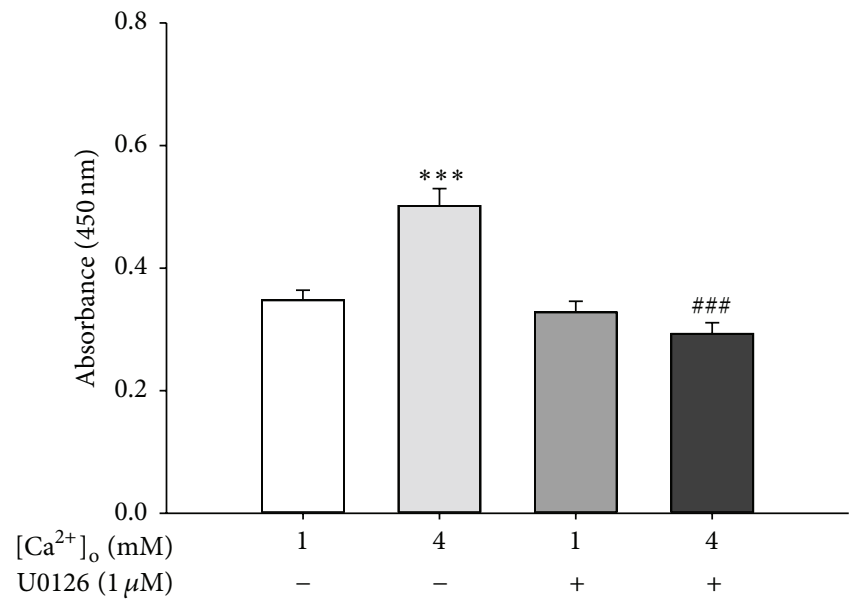

(a)

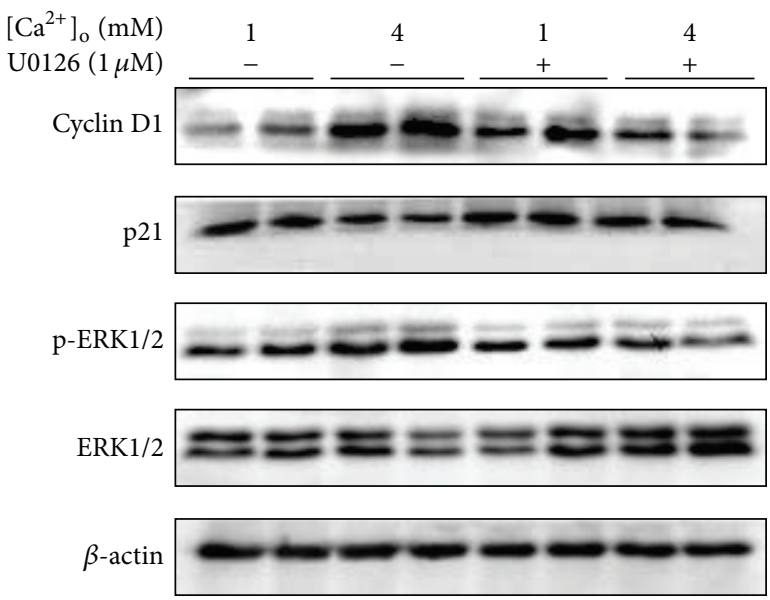

(c)

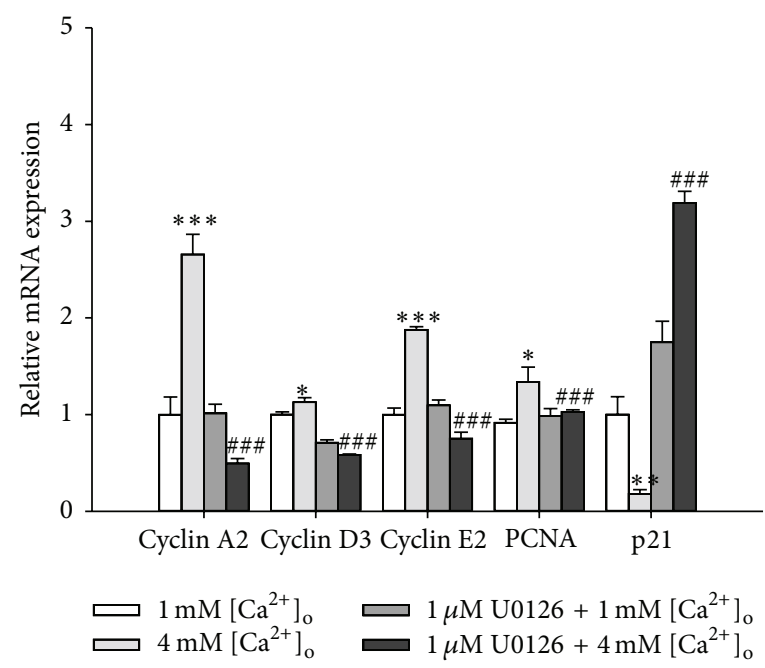

(b)

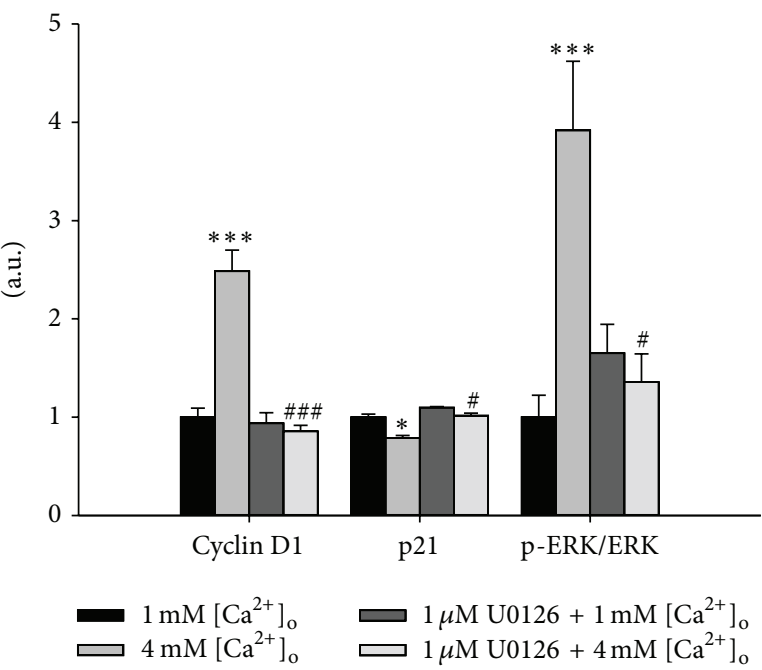

(d)

FIGURE 5: Inhibition of ERK pathway abolished $\left[\mathrm{Ca}^{2+}\right]_{\mathrm{o}}$-induced proliferation of pBMSCs. (a) Effects of U0126 (1 $\left.\mu \mathrm{M}\right)$, an inhibitor of MEK, on the proliferation of pBMSCs after 5-day incubation $(n=8)$. (b) The mRNA expression levels of cyclins (cyclin A2, cyclin D3, and cyclin E2), PCNA, and p21 in response to $4 \mathrm{mM}\left[\mathrm{Ca}^{2+}\right]_{\mathrm{o}}$ and/or $1 \mu \mathrm{M}$ U0126. (c) Western blot analysis of cyclin D1, p21, phosphor-ERK (p-ERK), and ERK in pBMSCs after 5-day culture. $\beta$-actin was used as loading control. (d) Mean \pm SEM of immunoblotting bands of cyclin D1, p21, and p-ERK/ERK. The intensities of the bands were expressed as the arbitrary units $(n=4) .{ }^{*} P<0.05$ and ${ }^{* * *} P<0.001$ versus $1 \mathrm{mM}\left[\mathrm{Ca}^{2+}\right]_{\mathrm{o}}$ group (control); ${ }^{\#} P<0.05$ and ${ }^{\# \#} P<0.001$ versus $4 \mathrm{mM}\left[\mathrm{Ca}^{2+}\right]_{\text {o }}$ group.

\section{Competing Interests}

The authors declare that they have no competing interests.

\section{Acknowledgments}

This work was supported by the National Natural Science Foundation of China (31372397), Guangdong Special Support Program (2014TQ01N260), and the Research Fund for the Doctoral Program of Higher Education of China (20124404130001).

\section{References}

[1] A. Uccelli, L. Moretta, and V. Pistoia, "Mesenchymal stem cells in health and disease," Nature Reviews Immunology, vol. 8, no. 9, pp. 726-736, 2008.

[2] S. Bajada, I. Mazakova, J. B. Richardson, and N. Ashammakhi, "Updates on stem cells and their applications in regenerative medicine," Journal of Tissue Engineering and Regenerative Medicine, vol. 2, no. 4, pp. 169-183, 2008.

[3] M. M. Swindle, A. Makin, A. J. Herron, F. J. Clubb Jr., and K. S. Frazier, "Swine as models in biomedical research and toxicology testing," Veterinary Pathology, vol. 49, no. 2, pp. 344-356, 2012. 
[4] M.-Q. Du, Y.-Q. Huang, N.-S. Lu et al., "Characterization and differentiation into adipocytes and myocytes of porcine bone marrow mesenchymal stem cells," Journal of Integrative Agriculture, vol. 13, no. 4, pp. 837-848, 2014.

[5] P. Bosch, S. L. Pratt, and S. L. Stice, "Isolation, characterization, gene modification, and nuclear reprogramming of porcine mesenchymal stem cells," Biology of Reproduction, vol. 74, no. 1, pp. 46-57, 2006.

[6] M. C. X. Pinto, A. H. Kihara, V. A. M. Goulart et al., "Calcium signaling and cell proliferation," Cellular Signalling, vol. 27, no. 11, pp. 2139-2149, 2015.

[7] M. D. Bootman, "Calcium signaling," Cold Spring Harbor Perspectives in Biology, vol. 4, no. 7, Article ID a011171, 2012.

[8] T. Yamaguchi, M. Yamauchi, T. Sugimoto et al., "The extracellular calcium $\left(\mathrm{Ca}_{o}^{2+}\right)$-sensing receptor is expressed in myeloma cells and modulates cell proliferation," Biochemical and Biophysical Research Communications, vol. 299, no. 4, pp. 532-538, 2002.

[9] A. Aguirre, A. González, J. A. Planell, and E. Engel, "Extracellular calcium modulates in vitro bone marrow-derived Flk $-1^{+} \mathrm{CD} 34^{+}$progenitor cell chemotaxis and differentiation through a calcium-sensing receptor," Biochemical and Biophysical Research Communications, vol. 393, no. 1, pp. 156-161, 2010.

[10] F. Hu, L. Pan, K. Zhang et al., "Elevation of extracellular $\mathrm{Ca} 2+$ induces store-operated calcium entry via calciumsensing receptors: a pathway contributes to the proliferation of osteoblasts," PLoS ONE, vol. 9, no. 9, Article ID e107217, 2014.

[11] G. Rocha, E. Villalobos, C. Fuentes et al., "Preadipocyte proliferation is elevated by calcium sensing receptor activation," Molecular and Cellular Endocrinology, vol. 412, pp. 251-256, 2015.

[12] H. Dry, K. Jorgenson, W. Ando, D. A. Hart, C. B. Frank, and A. Sen, "Effect of calcium on the proliferation kinetics of synovium-derived mesenchymal stromal cells," Cytotherapy, vol. 15, no. 7, pp. 805-819, 2013.

[13] A. S. Borowiec, G. Bidaux, N. Pigat, V. Goffin, S. Bernichtein, and T. Capiod, "Calcium channels, external calcium concentration and cell proliferation," European Journal of Pharmacology, vol. 739, pp. 19-25, 2014.

[14] W. G. Goodman, "Calcium-sensing receptors," Seminars in Nephrology, vol. 24, no. 1, pp. 17-24, 2004.

[15] K. Meng, J. Xu, C. Zhang et al., "Calcium sensing receptor modulates extracellular calcium entry and proliferation via TRPC3/6 channels in cultured human mesangial cells," PLoS ONE, vol. 9, no. 6, Article ID e98777, 2014.

[16] M. Peterlik, E. Kállay, and H. S. Cross, "Calcium nutrition and extracellular calcium sensing: relevance for the pathogenesis of osteoporosis, cancer and cardiovascular diseases," Nutrients, vol. 5, no. 1, pp. 302-327, 2013.

[17] W. Zhang and H. T. Liu, "MAPK signal pathways in the regulation of cell proliferation in mammalian cells," Cell Research, vol. 12, no. 1, pp. 9-18, 2002.

[18] M. Gooz Beck, E. N. Maldonado, Y. Dang et al., "ADAM17 promotes proliferation of collecting duct kidney epithelial cells through ERK activation and increased glycolysis in polycystic kidney disease," American Journal of Physiology-Renal Physiology, vol. 307, no. 5, pp. F551-F559, 2014.

[19] G. Liu, H. Hitomi, A. Rahman et al., "High sodium augments angiotensin II-induced vascular smooth muscle cell proliferation through the ERK 1/2-dependent pathway," Hypertension Research, vol. 37, no. 1, pp. 13-18, 2014.
[20] Y.-C. Huang, M. Pan, N. Liu, J.-G. Xiao, and H.-Q. Chen, "Effects of nuclear factor- $\kappa \mathrm{B}$ and ERK signaling transduction pathway inhibitors on human melanoma cell proliferation in vitro," Oncology Letters, vol. 10, no. 5, pp. 3233-3237, 2015.

[21] S. Torii, T. Yamamoto, Y. Tsuchiya, and E. Nishida, "ERK MAP kinase in $\mathrm{G}_{1}$ cell cycle progression and cancer," Cancer Science, vol. 97, no. 8, pp. 697-702, 2006.

[22] H.-Y. Wang, S.-L. Yang, H.-F. Liang, and C.-H. Li, "HBx protein promotes oval cell proliferation by up-regulation of cyclin D1 via activation of the MEK/ERK and PI3K/Akt pathways," International Journal of Molecular Sciences, vol. 15, no. 3, pp. 3507-3518, 2014.

[23] R. K. Dubey, J. Fingerle, D. G. Gillespie et al., "Adenosine attenuates human coronary artery smooth muscle cell proliferation by inhibiting multiple signaling pathways that converge on cyclin D," Hypertension, vol. 66, pp. 1207-1219, 2015.

[24] Y. Gao, H. Li, S. Liu, X. Zhang, and S. Sun, "Synergistic effect of fluconazole and doxycycline against Candida albicans biofilms resulting from calcium fluctuation and downregulation of fluconazole-inducible efflux pump gene overexpression," Journal of Medical Microbiology, vol. 63, no. 7, pp. 956-961, 2014.

[25] L. Xie, Y. Zheng, X. Li et al., "Enhanced proliferation of human hepatoma cells by PAR-2 agonists via the ERK/AP-1 pathway," Oncology Reports, vol. 28, no. 5, pp. 1665-1672, 2012.

[26] S. Wang, G. Zhou, G. Shu et al., "Glucose utilization, lipid metabolism and BMP-Smad signaling pathway of porcine intramuscular preadipocytes compared with subcutaneous preadipocytes," Cellular Physiology and Biochemistry, vol. 31, no. 6, pp. 981-996, 2013.

[27] G. Shu, N.-S. Lu, X.-T. Zhu et al., "Phloretin promotes adipocyte differentiation in vitro and improves glucose homeostasis in vivo," Journal of Nutritional Biochemistry, vol. 25, no. 12, pp. 1296-1308, 2014.

[28] Y. K. Liu, Q. Z. Lu, R. Pei et al., “The effect of extracellular calcium and inorganic phosphate on the growth and osteogenic differentiation of mesenchymal stem cells in vitro: implication for bone tissue engineering," Biomedical Materials, vol. 4, no. 2, Article ID 025004, 2009.

[29] E. Eklou-Kalonji, I. Denis, and A. Pointillart, "Influence of high concentrations of extracellular calcium on the proliferation and differentiation of porcine osteoblasts in culture," Reproduction Nutrition Development, vol. 37, no. 3, pp. 375-376, 1997.

[30] T.-M. Lin, J.-L. Tsai, S.-D. Lin, C.-S. Lai, and C.-C. Chang, "Accelerated growth and prolonged lifespan of adipose tissuederived human mesenchymal stem cells in a medium using reduced calcium and antioxidants," Stem Cells and Development, vol. 14, no. 1, pp. 92-102, 2005.

[31] G. D'Ippolito, S. Diabira, G. A. Howard, B. A. Roos, and P. C. Schiller, "Low oxygen tension inhibits osteogenic differentiation and enhances stemness of human MIAMI cells," Bone, vol. 39, no. 3, pp. 513-522, 2006.

[32] H. Ren, Y. Cao, Q. Zhao et al., "Proliferation and differentiation of bone marrow stromal cells under hypoxic conditions," Biochemical and Biophysical Research Communications, vol. 347, no. 1, pp. 12-21, 2006.

[33] D. P. Lennon, J. M. Edmison, and A. I. Caplan, "Cultivation of rat marrow-derived mesenchymal stem cells in reduced oxygen tension: effects on in vitro and in vivo osteochondrogenesis," Journal of Cellular Physiology, vol. 187, no. 3, pp. 345-355, 2001.

[34] X. Grana and E. P. Reddy, "Cell cycle control in mammalian cells: role of cyclins, cyclin dependent kinases (CDKs), growth 
suppressor genes and cyclin-dependent kinase inhibitors (CKIs)," Oncogene, vol. 11, no. 2, pp. 211-219, 1995.

[35] S. Lim and P. Kaldis, "Cdks, cyclins and CKIs: roles beyond cell cycle regulation," Development, vol. 140, no. 15, pp. 3079-3093, 2013.

[36] Z. Kelman, "PCNA: structure, functions and interactions," Oncogene, vol. 14, no. 6, pp. 629-640, 1997.

[37] L. Wen, Y. Wang, H. Wang et al., "L-type calcium channels play a crucial role in the proliferation and osteogenic differentiation of bone marrow mesenchymal stem cells," Biochemical and Biophysical Research Communications, vol. 424, no. 3, pp. 439445, 2012.

[38] Z. Xu, L. Yan, Y. Ge et al., "Effect of the calcium sensing receptor on rat bone marrow-derived mesenchymal stem cell proliferation through the ERK1/2 pathway," Molecular Biology Reports, vol. 39, no. 7, pp. 7271-7279, 2012.

[39] G. Molostvov, S. Fletcher, R. Bland, and D. Zehnder, "Extracellular calcium-sensing receptor mediated signalling is involved in human vascular smooth muscle cell proliferation and apoptosis," Cellular Physiology and Biochemistry, vol. 22, no. 5-6, pp. 413-422, 2008.

[40] O. Rey, S. H. Young, R. Jacamo, M. P. Moyer, and E. Rozengurt, "Extracellular calcium sensing receptor stimulation in human colonic epithelial cells induces intracellular calcium oscillations and proliferation inhibition," Journal of Cellular Physiology, vol. 225, no. 1, pp. 73-83, 2010.

[41] M. Brini, T. Calì, D. Ottolini, and E. Carafoli, "Intracellular calcium homeostasis and signaling," Metal Ions in Life Sciences, vol. 12, pp. 119-168, 2013.

[42] J. Choi, A. Chiang, N. Taulier, R. Gros, A. Pirani, and M. Husain, "A calmodulin-binding site on cyclin E mediates $\mathrm{Ca}^{2+}$-sensitive G1/S transitions in vascular smooth muscle cells," Circulation Research, vol. 98, no. 10, pp. 1273-1281, 2006.

[43] J. Tfelt-Hansen, N. Chattopadhyay, S. Yano et al., "Calciumsensing receptor induces proliferation through p38 mitogenactivated protein kinase and phosphatidylinositol 3-kinase but not extracellularly regulated kinase in a model of humoral hypercalcemia of malignancy," Endocrinology, vol. 145, no. 3, pp. 1211-1217, 2004. 

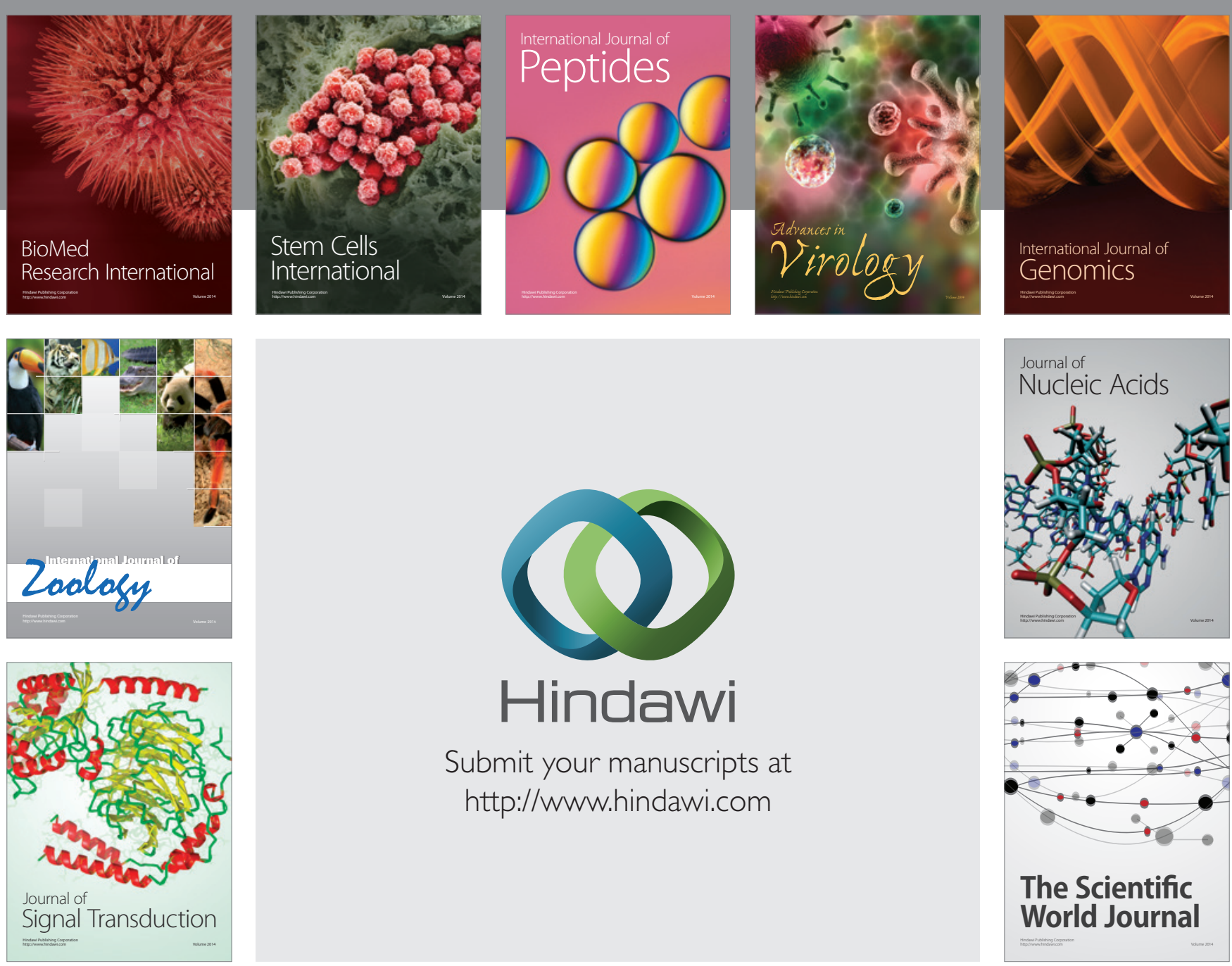

Submit your manuscripts at

http://www.hindawi.com
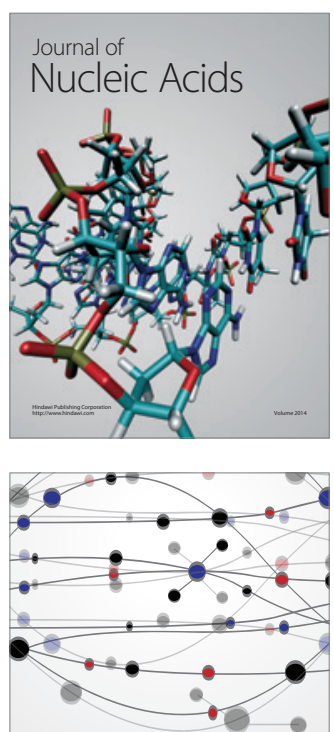

The Scientific World Journal
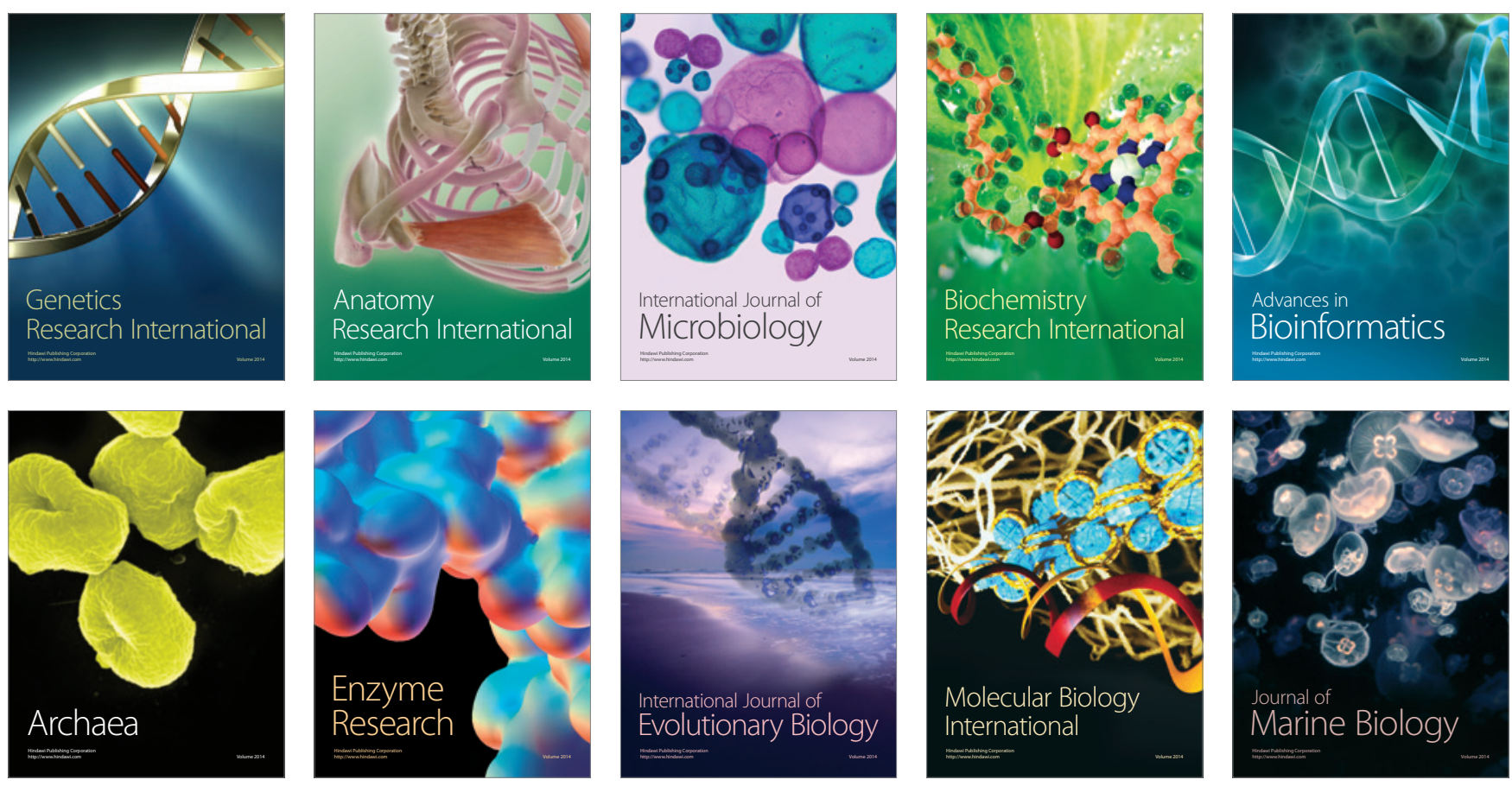